\title{
Acidomonas gen. nov., Incorporating Acetobacter methanolicus as Acidomonas methanolica comb. nov.
}

\author{
TEIZI URAKAMII, ${ }^{*}$ JIN TAMAOKA,${ }^{2}$ KEN-ICHIRO SUZUKI,${ }^{3}$ AND KAZUO KOMAGATA ${ }^{2}$ \\ Niigata Research Laboratory, Mitsubishi Gas Chemical Co., Tayuhama, Niigata 950-31, Japan ${ }^{1}$; Institute of Applied \\ Microbiology, The University of Tokyo, Bunkyo-ku, Tokyo 113, Japan ${ }^{2}$; and Japan Collection of Microorganisms, The \\ Institute of Physical and Chemical Research, Wako-shi, Saitama 351-01, Japan ${ }^{3}$
}

\begin{abstract}
A new genus of acidophilic, facultatively methylotrophic bacteria is described. These organisms are gram-negative, nonsporeforming, nonmotile; and rod shaped and grow at $\mathrm{pH} \mathrm{2.0}$ to 5.5. These characteristics are unique among the methanol-utilizing bacteria. The deoxyribonucleic acid base composition is 63 to 65 mol\% guanine plus cytosine. Acetobacter methanolicus $\mathrm{TK}_{0705}^{\mathrm{T}}(\mathrm{T}=$ type strain) is a typical strain in this group. These bacteria are distinguished from type and representative strains of Acetobacter, Gluconobacter, Acidiphilium, and Thiobacillus on the basis of deoxyribonucleic acid-deoxyribonucleic acid homology. A new genus, Acidomonas, is proposed to include this group of methylotrophic bacteria. The type species of the genus Acidomonas is Acidomonas methanolica comb. nov., with type strain TK 0705 (= IMET 10945).
\end{abstract}

We have reported previously $(24,25,27)$ the grouping of gram-negative, methanol-utilizing bacteria into 11 groups on the basis of morphological characteristics, utilization of carbon compounds, cellular fatty acid composition, hydroxy fatty acid composition, ubiquinone systems, occurrence of squalene and steroids, and electrophoretic patterns of enzymes.

The group 7 bacteria of that previous study $(24,25)$ are acidophilic, facultatively methylotrophic, nonsporeforming, gram-negative, nonmotile, rod-shaped organisms. Steudel et al. (18) isolated a comparable bacterium, strain B58, which utilized methanol and grew at $\mathrm{pH} 4.0$ to 4.2 , and Uhlig et al. (21) named this organism Acetobacter methanolicus in 1986.

In this study we determined that the group 7 bacteria are identical to Acetobacter methanolicus, but we believe that the methylotrophic ability of these organisms demands a new genus, for which we propose the name Acidomonas.

\section{MATERIALS AND METHODS}

Bacterial strains. The strains which we studied are shown in Table 1. Below, names which do not appear on the Approved Lists of Bacterial Names (17) are enclosed in quotation marks. Cultures were maintained on peptoneyeast extract-malt extract agar containing $0.5 \%$ peptone, $0.3 \%$ yeast extract, $0.3 \%$ malt extract, $1.0 \%$ glucose, and $2.0 \%$ agar; this medium was adjusted to $\mathrm{pH} 4.5$ with $1 \mathrm{~N} \mathrm{HCl}$ (PYM medium). Acetobacter pasteurianus TK 0724, TK 0728, and TK 0729 were received from J. De Ley as methanol-utilizing bacteria. Thiobacillus novellus TK $0901^{\mathrm{T}}$ ( $\mathrm{T}=$ type strain) and Thiobacillus versutus $\mathrm{TK} 3101^{\mathrm{T}}$ were used as reference strains. $T$. novellus TK $0901^{\mathrm{T}}$ was a member of the group 9 methanol-utilizing bacteria that we described previously, and T. versutus TK $3101^{\mathrm{T}}$ was a member of the group 2 methylamine-utilizing bacteria which we described previously $(24,25)$. These two strains were maintained on peptone-yeast extract-glucose agar containing $0.5 \%$ peptone, $0.5 \%$ yeast extract, $0.5 \%$ glucose, and $2.0 \%$ agar; this medium was adjusted to pH 6.8 with $1 \mathrm{M} \mathrm{NaOH}$.

Identification methods. PYM medium ( $\mathrm{pH} \mathrm{4.5)}$ and medium $\mathrm{C}$ (24) containing methanol were used for preculture and basal media. Unless otherwise stated, all cultures were

\footnotetext{
* Corresponding author.
}

incubated at $30^{\circ} \mathrm{C}$. Cell form, Gram reaction, and motility were investigated by using cells grown on PYM medium $(\mathrm{pH}$ 4.5) and medium C. Biochemical and physiological characteristics were investigated as reported previously (23). However, the $\mathrm{pH}$ of media was adjusted to 4.5 . Ketogenic activity on polyalcohols (production of dihydroxyacetone from glycerol) was tested by using the method of Asai et al. (1). Acetic acid produced from ethanol was detected by gas chromatography. Nutritional requirements were determined by using a basal medium without yeast extract and the vitamin solution in medium $C$. Urease activity was observed on Christensen medium (2) for 1 week. Utilization of carbon compounds was determined in liquid basal medium $\mathrm{C}$ or medium B (22) (for T. novellus and T. versutus) after 3 weeks of cultivation, and methanol was replaced with other carbon compounds. Acetic acid, citric acid, lactic acid, monomethylamine, dimethylamine, and trimethylamine were added at concentrations of $0.15 \%$. A total of 17 carbon compounds were added at concentrations of $0.5 \%$.

Cellular fatty acid composition. Cellular fatty acid composition and hydroxy acid composition were determined as described previously (25).

Quinone system and quinone homologs. Quinone systems were determined as described previously (24).

DNA base composition. Deoxyribonucleic acid (DNA) was extracted by using the method of Saito and Miura (16), and guanine-plus-cytosine $(\mathrm{G}+\mathrm{C})$ content was determined by reverse-phase high-performance liquid chromatography as described by Tamaoka and Komagata (19).

DNA-DNA hybridization. DNA-DNA hybridization was carried out at $61^{\circ} \mathrm{C}$ by using the method of Kaneko et al. (13). DNA was labeled with $\left[1^{\prime}, 2{ }^{\prime}, 5-{ }^{3} \mathrm{H}\right]$ deoxycytidine triphosphate by the nick translation method (15), using Amersham Kit TRK 700 (Amersham International plc, Amersham, United Kingdom). DNA-DNA hybridization was carried out with five strains of the group 7 methanol-utilizing bacteria, seven strains of the genus Acetobacter, one strain of the genus Gluconobacter, four strains of the genus Acidiphilium, and two strains of the genus Thiobacillus.

\section{RESULTS}

Phenotypic characteristics of the group 7 bacteria. Five of the strains studied (strains TK 0701, TK 0702, TK 0703, and TK 0704 and Acetobacter methanolicus TK 0705 ${ }^{\mathrm{T}}$ ) were 
TABLE 1. Bacterial strains studied

\begin{tabular}{|c|c|c|}
\hline Strain & Source ${ }^{a}$ & Reference(s) \\
\hline Acetobacter methanolicus TK $0705^{\mathrm{T}}$ & IMET 10945 (= Steudel et al. B58) & 18,21 \\
\hline "Acetobacter sadu" TK 0701 & Urakami et al. BNS-25 (= JCM $3712=$ FERM P-2664) & $24,25^{b}$ \\
\hline Isolate TK 0702 & Urakami et al. $\mathrm{I}-2$ & 24,25 \\
\hline Isolate TK 0703 & Urakami et al. $\mathrm{T}-101$ & 24,25 \\
\hline Isolate TK 0704 & Urakami et al. EC-1 & 24,25 \\
\hline Acidiphilium cryptum TK $0711^{\mathrm{T}}$ & IFO 14242 (= Harrison et al. Lhe 2) & 7,9 \\
\hline Acidiphilium cryptum TK 0712 & Harrison et al. $\mathrm{m}-5$ & 7,9 \\
\hline Acidiphilium cryptum TK 0713 & Harrison et al. KG-4 & 7,9 \\
\hline Acidiphilium angustum TK $0714^{\mathrm{T}}$ & ATCC 35903 & 28 \\
\hline Acidiphilium facilis TK $0715^{\mathrm{T}}$ & ATCC 35904 & 28 \\
\hline Acidiphilium sp. strain TK 0718 & IFO 14243 (= Harrison et al. 44 het) & \\
\hline Acetobacter aceti $\mathrm{TK} 0720^{\mathrm{T}}$ & NCIB 8621 & 3 \\
\hline Acetobacter pasteurianus TK $0721^{\mathrm{T}}$ & NCIB 12228 & 3 \\
\hline Acetobacter pasteurianus TK 0724 & Gossele et al. LMG-1617 (= NICB 8620) & 3,5 \\
\hline Acetobacter pasteurianus TK 0728 & Gossele et al. LMG-1701 (= VV3) & 3,5 \\
\hline Acetobacter pasteurianus TK 0729 & Gossele et al. LMG-1804 (= NCPPB 462) & 3,5 \\
\hline Acetobacter xylinum TK $0731^{\mathrm{T}}$ & NCIB 11664 & 12,29 \\
\hline Acetobacter hansenii TK $0735^{\mathbf{T}}$ & NCIB 8746 & $3,5,10$ \\
\hline Acetobacter liquefaciens TK $0736^{\mathrm{T}}$ & IAM 1834 & $3,5,10,32$ \\
\hline Acetobacter liquefaciens TK 0737 & IAM 1835 & $3,5,10,32$ \\
\hline Acetobacter liquefaciens TK 0738 & IAM 1836 & $3,5,10,32$ \\
\hline Gluconobacter oxydans TK $0740^{\mathrm{T}}$ & NCIB 9013 & 3 \\
\hline Gluconobacter cerinus TK $0745^{\mathrm{T}}$ & IFO 3267 & 11,31 \\
\hline T. acidophilus TK $0719^{\mathrm{T}}$ & ATCC 27807 & 6,8 \\
\hline T. novellus TK $0901^{\mathrm{T}}$ & NCIB 9113 & 20 \\
\hline T. versutus TK $3101^{\mathrm{T}}$ & ATCC 25364 & 8 \\
\hline
\end{tabular}

${ }^{a}$ Abbreviations for culture collections: ATCC, American Type Culture Collection, Rockville, Md.; FERM, Fermentation Research Institute, Agency of Industrial Science and Technology, Ibaragi, Japan; IAM, Institute of Applied Microbiology, The University of Tokyo, Tokyo, Japan; IFO, Institute for Fermentation, Osaka, Japan; IMET, Zentralinstitut für Mikrobilogie und Experimentelle of Therapie, Akademie der Wissenschaften der DDR, Jena, East German Democratic Republic; JCM, Japan Collection of Microorganisms, Institute of Physical and Chemical Research, Wako-shi, Saitama, Japan; NCIB, National Collection of Industrial Bacteria, Aberdeen, United Kingdom; NCPPB, National Collection of Plant Pathogenic Bacteria, Harpenden, United Kingdom.

${ }^{b}$ Urakami, Japan patent $1,073,957$, May 1981 .

phenotypically similar, gram-negative, nonsporeforming, nonmotile, rod-shaped organisms that were 0.8 to $1.0 \mu \mathrm{m}$ in diameter and 1.5 to $3.0 \mu \mathrm{m}$ long. Colonies were white to light yellow on PYM medium ( $\mathrm{pH} \mathrm{4.5)} \mathrm{and} \mathrm{medium} \mathrm{C.} \mathrm{A} \mathrm{water-}$ soluble fluorescent pigment was not produced on King A and King B media adjusted $\mathrm{pH}$ to 4.5 . Nitrate was not reduced to nitrite. The Voges-Proskauer test was negative. Indole and hydrogen sulfide (TSI medium adjusted $\mathrm{pH} 4.5$ ) were not

TABLE 2. Utilization of carbon compounds by the group 7 methanol-utilizing bacteria and strains of Acidiphilium cryptum,

Thiobacillus species, and Acetobacter liquefaciens

Strain

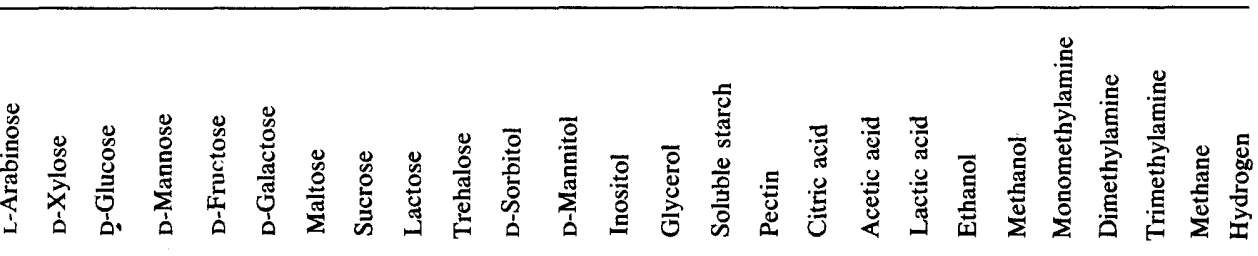

Acetobacter methanolicus TK $0705^{\mathrm{T}}$ "Acetobacter sadu" TK 0701 Isolate $\mathrm{I}-2$ (= TK 0702)

Isolate T-101 (= TK 0703)

Isolate EC-1 (= TK 0704)

Acidiphilium cryptum TK $0711^{\mathrm{T}}$

Acidiphilium cryptum TK 0712

Acidiphilium cryptum TK 0713

Acidiphilium sp. strain TK 0718

T. acidophilus TK $0719^{\mathrm{T}}$

$T$. novellus TK $0901^{\mathrm{T}}$

$T$. versutus TK $3101^{\mathrm{T}}$

Acetobacter liquefaciens TK $0736^{\mathrm{T}}$

Acetobacter liquefaciens TK 0737

Acetobacter liquefaciens TK 0738

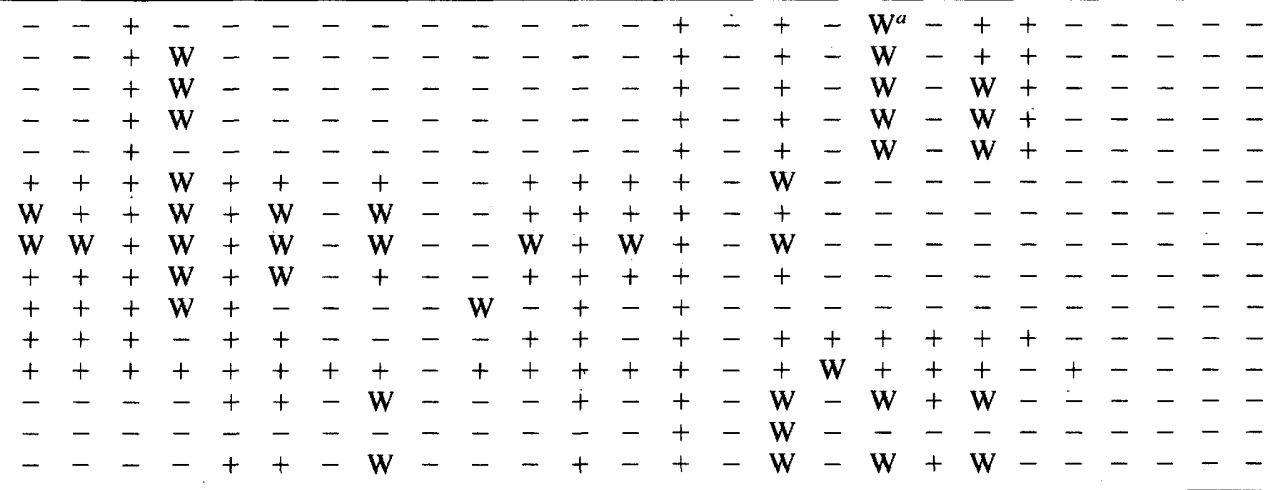

${ }^{a} \mathrm{~W}$, Weak. 
produced. Hydrolysis of gelatin and starch was not observed. Ammonia was produced. Denitrification was not performed. Litmus milk was not changed. Dihydroxyacetone from glycerol was not produced. Acetic acid was produced from ethanol. Acid was produced from D-glucose oxidatively, but not from L-arabinose, D-xylose, D-mannose, D-fructose, D-galactose, maltose, sucrose, lactose, trehalose, D-sorbitol, D-mannitol, inositol, glycerol, or soluble starch. Acid was not produced fermentatively. All of the strains grew at the expense of methanol, ethanol, acetic acid, D-glucose, glycerol, and pectin, but did not grow at the expense of L-arabinose, D-xylose, D-fructose, D-galactose, maltose, sucrose, lactose, trehalose, D-sorbitol, D-mannitol, inositol, soluble starch, citric acid, lactic acid, monomethylamine, dimethylamine, trimethylamine, methane, or hydrogen. Some strains utilized D-mannose weakly (Table 2). Calcium pantothenate was required. Ammonia, nitrate, and urea were utilized by all of the strains as nitrogen sources. Urease, oxidase, and catalase were produced. Growth was observed between $\mathrm{pH} 2.0$ and 5.5; the organisms did not grow at $\mathrm{pH} 1.5$ and 6.0 . The optimum cultural $\mathrm{pH}$ was 3.0 to 5.0 , and the maximum specific growth rate was approximately $0.25 \mathrm{~h}^{-1}$. All of the strains grew at 30 and $37^{\circ} \mathrm{C}$, but did not grow at $42^{\circ} \mathrm{C}$. Growth did not occur in the presence of $3 \%$ sodium chloride.

The group 7 bacteria were distinguished from the confusing Acidiphilium, Thiobacillus, and Acetobacter strains on the basis of utilization of carbon compounds (Table 2). All of the reference strains belonging to the genera Acidiphilium, Acetobacter, and Gluconobacter did not utilize methanol.

Cellular fatty acid composition. The reference strains belonging to the genera Acidiphilium, Acetobacter, and Gluconobacter contained large amounts of straight-chain unsaturated $\mathrm{C}_{18: 1}$ acid, as did the group 7 methanol-utilizing bacteria (25) and Thiobacillus strains $(14,25)$ (Table 3$)$. The cellular fatty acid compositions of Acetobacter and Gluconobacter strains were determined by Yamada et al. (34). We confirmed these earlier results.

Hydroxy fatty acid composition. The group 7 methanolutilizing bacteria had large amounts of $3-\mathrm{OH} \mathrm{C}_{14: 0}$ acid, 3-OH C $\mathrm{C}_{16: 0}$ acid, 2-OH C $\mathrm{C}_{14: 0}$ acid, and 2-OH $\mathrm{C}_{16: 0}$ acid (25). All of the Acidiphilium strains except Acidiphilium facilis TK $0715^{\mathrm{T}}$ showed the presence of 3-hydroxy fatty acid, but not 2-hydroxy fatty acid, as shown in Table 3 . All of the strains of the genera Acetobacter and Gluconobacter showed the presence of large amounts of 3-OH $\mathrm{C}_{16: 0}$ and 2-OH $\mathrm{C}_{16: 0}$ hydroxy acids and small amounts of 3-OH $\mathrm{C}_{14: 0}$ and 3-OH $\mathrm{C}_{18: 0}$ hydroxy acids, as well as $2-\mathrm{OH} \mathrm{C}_{14: 0}$ and 2-OH cyclopropane $\mathrm{C}_{19: 0}\left(2-\mathrm{OH} \Delta \mathrm{C}_{19: 0}\right)$ acids.

Quinone system. The group 7 methanol-utilizing bacteria had the Q-10 ubiquinone system along with ubiquinone Q-9 and minor ubiquinone Q-11 components (24). The reference strains belonging to the genera Acidiphilium, Thiobacillus $(14,24)$, and Gluconobacter had the Q-10 ubiquinone system, along with minor ubiquinone Q-9 and Q-11 components. Acetobacter strains were divided into two types (Q-9 and Q-10 types), as shown in Table 3. The same results for quinone systems in Acetobacter species (except Acetobacter hansenii) and Gluconobacter species were reported by Yamada et al. (30).

DNA base composition. The DNA base compositions of five strains of the group 7 methanol-utilizing bacteria ranged from 63.7 to $64.6 \mathrm{~mol} \% \mathrm{G}+\mathrm{C}$. The DNA compositions of the reference strains are shown in Table 4. The DNA base compositions of Acetobacter methanolicus, Acidiphilium cryptum, Acidiphilium angustum, and Acetobacter aceti

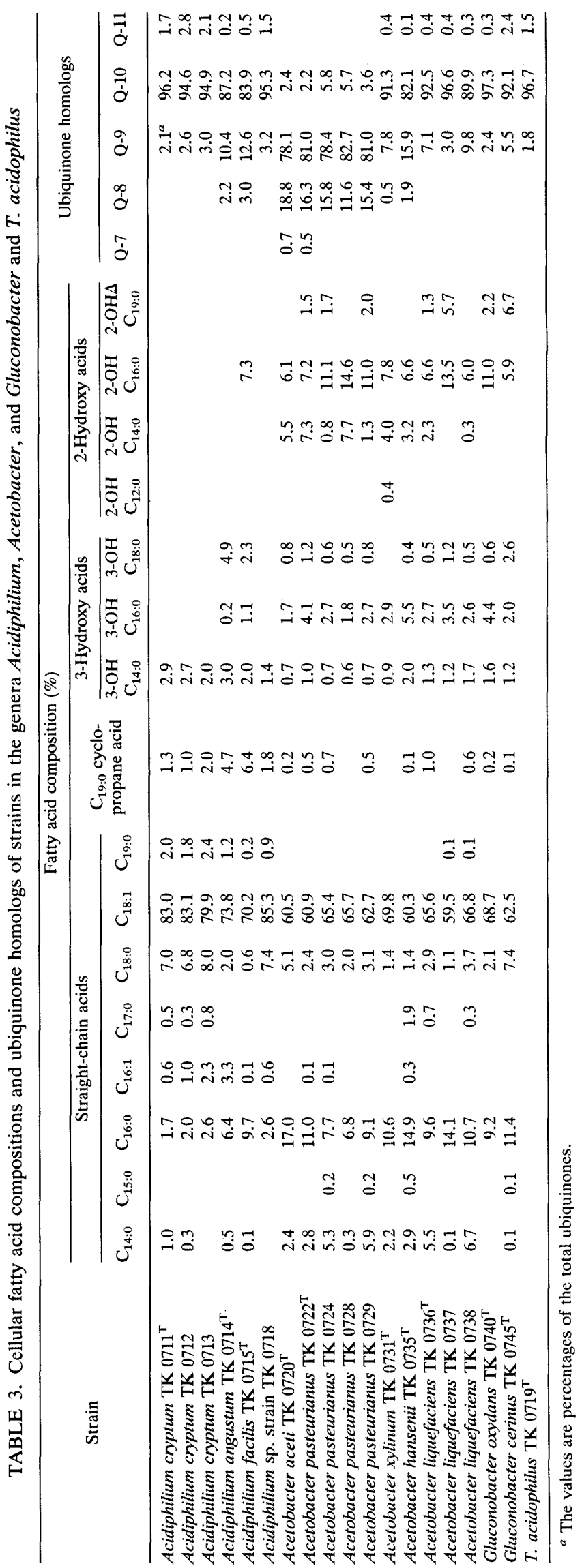


TABLE 4. DNA base compositions, cellular fatty acid compositions, hydroxy fatty acid compositions, ${ }^{k}$ and ubiquinone types of the group 7 methanol-utilizing bacteria and strains in the genera Acidiphilium, Acetobacter, Gluconobacter, and Thiobacillus

\begin{tabular}{|c|c|c|c|c|c|c|}
\hline \multirow{2}{*}{ Strain } & \multicolumn{2}{|c|}{$\mathrm{G}+\mathrm{C}$ content $(\mathrm{mol} \%)$} & \multirow{2}{*}{$\begin{array}{l}\text { Major cellular } \\
\text { fatty acid }\end{array}$} & \multirow{2}{*}{$\begin{array}{l}\text { Major 3-hydroxy } \\
\text { fatty acid(s) }\end{array}$} & \multirow{2}{*}{$\begin{array}{l}\text { Major 2-hydroxy } \\
\text { fatty acid }\end{array}$} & \multirow{2}{*}{$\begin{array}{l}\text { Quinone } \\
\text { type }\end{array}$} \\
\hline & This study & Other study & & & & \\
\hline Acetobacter methanolicus TK $0715^{\mathrm{T}}$ & 64.4 & $62.3^{a}$ & $\mathrm{C}_{18: 1^{b}}$ & $C_{16: 0}\left(C_{14: 0}\right)^{b}$ & $\mathrm{C}_{16: 0}\left(\mathrm{C}_{14: 0}\right)^{b}$ & Q-10 \\
\hline “Acetobacter sadu" TK 0701 & 64.2 & $64.6^{d}$ & $\mathrm{C}_{18: 1}^{18: 1}$ & $\mathrm{C}_{16: 0}\left(\mathrm{C}_{14: 0}\right)^{b}$ & $\mathrm{C}_{16: 0}^{16: 0}\left(\mathrm{C}_{14: 0}\right)^{b}$ & $\mathrm{Q}-10^{c}$ \\
\hline Isolate $\mathrm{I}-2(=\mathrm{TK} 0702)$ & 64.1 & $65.1^{d}$ & $\mathrm{C}_{18: 1}^{18: 1}$ & $\mathrm{C}_{16: 0}\left(\mathrm{C}_{14: 0}, \mathrm{C}_{10: 0}\right)^{b}$ & $\mathrm{C}_{16: 0}\left(\mathrm{C}_{14: 0}\right)^{b}$ & $\mathrm{Q}-10^{c}$ \\
\hline Isolate $\mathrm{T}-101(=\mathrm{TK} 0703)$ & 63.7 & $63.7^{d}$ & $\mathrm{C}_{18: 1^{b}}$ & $\mathrm{C}_{16: 0}\left(\mathrm{C}_{14: 0}\right)^{b}$ & $\mathrm{C}_{16: 0}\left(\mathrm{C}_{14: 0}\right)^{b}$ & $Q-10^{c}$ \\
\hline Isolate EC-1 (= TK 0704) & 64.6 & $64.1^{d}$ & $\mathrm{C}_{18: 1}{ }^{b}$ & $\mathrm{C}_{16: 0}\left(\mathrm{C}_{14: 0}\right)^{b}$ & $C_{16: 0}\left(C_{14: 0}\right)^{b}$ & $\mathrm{Q}-10^{c}$ \\
\hline Acidiphilium cryptum TK $0711^{\mathrm{T}}$ & 66.2 & $69.4^{e}$ & $\mathrm{C}_{18: 1}^{10.1}$ & $\mathrm{C}_{14: 0}$ & & Q-10 \\
\hline Acidiphilium cryptum TK 0712 & & $70.0^{e}$ & $\mathrm{C}_{18: 1}^{10.1}$ & $\mathrm{C}_{14: 0}^{140}$ & & Q-10 \\
\hline Acidiphilium cryptum TK 0713 & & $68.1^{e}$ & $C_{18: 1}^{18: 1}$ & $C_{14: 0}^{14: 0}$ & & Q-10 \\
\hline Acidiphilium angustum TK $0714^{\mathrm{T}}$ & 62.3 & $67^{f}$ & $\mathrm{C}_{18: 1}$ & $\mathrm{C}_{18: 0}^{14: 0}\left(\mathrm{C}_{14: 0}\right)$ & & Q-10 \\
\hline Acidiphilium facilis TK $0715^{\mathrm{T}}$ & 64.0 & $65^{f}$ & $\mathrm{C}_{18: 1}$ & $\mathrm{C}_{14: 0}, \mathrm{C}_{18: 0}\left(\mathrm{C}_{16: 0}\right)$ & $C_{16: 0}$ & Q-10 \\
\hline Acidiphilium sp. strain TK 0718 & 66.2 & & $\mathrm{C}_{18: 1}$ & $\mathrm{C}_{14: 0}$ & & Q-10 \\
\hline Acetobacter aceti $\mathrm{TK} 0720^{\mathrm{T}}$ & 56.5 & $58.6^{g}$ & $\mathrm{C}_{18: 1}$ & $\mathrm{C}_{16: 0}\left(\mathrm{C}_{14: 0}, \mathrm{C}_{18: 0}\right)$ & $\mathrm{C}_{16: 0}\left(\mathrm{C}_{14: 0}\right)$ & Q-9 \\
\hline Acetobacter pasteurianus TK $0722^{\mathrm{T}}$ & 53.0 & & $\mathrm{C}_{18: 1}^{181}$ & $\mathrm{C}_{16: 0}\left(\mathrm{C}_{14: 0}, \mathrm{C}_{18: 0}\right)$ & $C_{16: 0}^{16: 0}\left(C_{14: 0}, \Delta C_{19: 0}\right)$ & Q-9 \\
\hline Acetobacter pasteurianus TK 0724 & 57.2 & $58.0^{h}$ & $\mathrm{C}_{18: 1}^{10.1}$ & $\mathrm{C}_{16: 0}\left(\mathrm{C}_{14: 0}, \mathrm{C}_{18: 0}\right)$ & $C_{16: 0}^{16: 0}\left(\Delta C_{19: 0}\right)$ & Q-9 \\
\hline Acetobacter pasteurianus TK 0728 & & & $\mathrm{C}_{18: 1}$ & $\mathrm{C}_{16: 0}\left(\mathrm{C}_{14: 0}\right)$ & $C_{16: 0}\left(C_{14: 0}\right)$ & Q-9 \\
\hline Acetobacter pasteurianus TK 0729 & 56.9 & & $\mathrm{C}_{18: 1}$ & $\mathrm{C}_{16: 0}\left(\mathrm{C}_{14: 0}, \mathrm{C}_{18: 0}\right)$ & $\mathrm{C}_{16: 0}\left(\Delta \mathrm{C}_{19: 0}\right)$ & Q-9 \\
\hline Acetobacter xylinum TK $0731^{\mathrm{T}}$ & 61.5 & & $\mathrm{C}_{18: 1}$ & $\mathrm{C}_{16: 0}\left(\mathrm{C}_{14: 0}, \mathrm{C}_{18: 0}\right)$ & $C_{16: 0}^{10.0}\left(C_{14: 0}\right)$ & Q-10 \\
\hline Acetobacter hansenii TK $0735^{\mathrm{T}}$ & 58.5 & $59.7^{h}$ & $\mathrm{C}_{18: 1}$ & $C_{16: 0}\left(C_{14: 0}\right)$ & $C_{16: 0}\left(C_{14: 0}^{140}\right)$ & $\mathrm{Q}-10$ \\
\hline Acetobacter liquefaciens TK $0736^{\mathrm{T}}$ & 64.2 & $64.5^{g}$ & $\mathrm{C}_{18: 1}^{10.1}$ & $\mathrm{C}_{16: 0}\left(\mathrm{C}_{14: 0}, \mathrm{C}_{18: 0}\right)$ & $\mathrm{C}_{16: 0}\left(\mathrm{C}_{14: 0}, \Delta \mathrm{C}_{19: 0}\right)$ & Q-10 \\
\hline Acetobacter liquefaciens TK 0737 & & $66.2^{g}$ & $\mathrm{C}_{18: 1}$ & $\mathrm{C}_{16: 0}\left(\mathrm{C}_{14: 0}, \mathrm{C}_{18: 0}\right)$ & $\mathrm{C}_{16: 0}\left(\Delta \mathrm{C}_{19: 0}\right)$ & $\mathrm{Q}-10$ \\
\hline Acetobacter liquefaciens TK 0738 & & $64.0^{g}$ & $C_{18: 1}^{10.1}$ & $\mathrm{C}_{16: 0}\left(\mathrm{C}_{14: 0}, \mathrm{C}_{18: 0}\right)$ & $\mathrm{C}_{16: 0}$ & $\mathrm{Q}-10$ \\
\hline Gluconobacter oxydans TK $0740^{\mathrm{T}}$ & 60.1 & $60.6^{8}$ & $\mathrm{C}_{18: 1}$ & $\mathrm{C}_{16: 0}\left(\mathrm{C}_{14: 0}, \mathrm{C}_{18: 0}\right)$ & $C_{16: 0}\left(\Delta C_{19: 0}\right)$ & Q-10 \\
\hline Gluconobacter cerinus TK $0745^{\mathrm{T}}$ & 55.8 & $55.7^{g}$ & $\mathrm{C}_{18: 1}^{10: 1}$ & $\mathrm{C}_{14: 0}, \mathrm{C}_{16: 0}, \mathrm{C}_{18: 0}$ & $\mathrm{C}_{16: 0}, \Delta \mathrm{C}_{19: 0}$ & Q-10 \\
\hline T. acidophilus TK $0719^{\mathrm{T}}$ & & $62.9-63.2^{i}$ & $\mathrm{C}_{18: 1}{ }^{10.1}$ & $\mathrm{C}_{14: 0^{i}}$ & & Q-10 \\
\hline T. novellus TK $0901^{\mathrm{T}}$ & 66.9 & $67.7^{d}$ & $\mathrm{C}_{18: 1}^{10.1}$ & $C_{14: 0}^{14.0}\left(C_{10: 0}\right)$ & & $Q-10^{c}$ \\
\hline T. versutus TK $3101^{\mathrm{T}}$ & 67.2 & $68.0^{j}$ & $\mathrm{C}_{18: 1}^{b}$ & $C_{10: 0}\left(C_{14: 0}, C_{16: 0}\right)$ & & $\mathrm{Q}-10^{c}$ \\
\hline
\end{tabular}

${ }^{a}$ Data from reference 21

${ }^{b}$ Data from reference 25

$c$ Data from reference 24 .

${ }^{d}$ Data from reference 26

e Data from reference 7 .

$f$ Data from reference 28 .

$g$ Data from reference 33

${ }^{h}$ Data from reference 4.

${ }^{i}$ Data from reference 14 .

Data from reference 8 .

${ }^{k}$ Parentheses indicate minor components.

determined in this study were different from the results reported by other workers $(6,20,28,33)$. The differences among the results may be ascribed to assay methods.

DNA-DNA homologies. The levels of DNA-DNA homology among the group 7 methanol-utilizing bacteria and the reference strains clearly indicate a separation of the group 7 strains from the strains belonging to the genera Acidiphilium, Acetobacter, and Gluconobacter, as shown in Table 5. Furthermore, five strains (TK 0701, TK 0702, TK 0703, TK 0704 , TK $0705^{\mathrm{T}}$ ) showed high levels of similarity to each other. The reference strains belonging to the genera Acidiphilium, Acetobacter, and Gluconobacter showed low levels of similarity each other. An exception was Acidiphilium sp. strain TK 0718 and Acidiphilium crytpum, which showed a relatively high similarity value.

\section{DISCUSSION}

The five strains of group 7 methanol-utilizing bacteria grew at $\mathrm{pH} 2.0$ to 5.5, and this characteristic is unique among the methanol-utilizing bacteria. They shared almost the same phenotypic characteristics, as well as the same cellular fatty acid composition (25), hydroxy fatty acid composition (25), ubiquinone system (24), and DNA base composition. The strains which we studied showed high levels of similarity in
TABLE 5. DNA-DNA homologies among the group 7 methanol-utilizing bacteria and strains in the genera Acetobacter, Gluconobacter, Acidiphilium, and Thiobacillus

\begin{tabular}{|c|c|c|c|c|}
\hline \multirow{2}{*}{ Strain } & \multicolumn{4}{|c|}{$\begin{array}{l}\text { \% DNA-DNA homology } \\
\text { with strain: }\end{array}$} \\
\hline & $\begin{array}{l}\text { TK } \\
0705^{\mathrm{T}}\end{array}$ & $\begin{array}{c}\text { TK } \\
0720\end{array}$ & $\begin{array}{c}\text { TK } \\
0740\end{array}$ & $\begin{array}{c}\text { TK } \\
0711\end{array}$ \\
\hline Acetobacter methanolicus TK $0705^{\mathrm{T}}$ & 100 & 13 & 8 & 10 \\
\hline "Acetobacter sadu" TK 0701 & 107 & 14 & 10 & 14 \\
\hline Isolate I-2 (= TK 0702) & 95 & 13 & 12 & 16 \\
\hline Isolate T-101 (= TK 0703) & 89 & 12 & 9 & 11 \\
\hline Isolate EC-1 (= TK 0704) & 101 & 14 & 11 & 14 \\
\hline Acetobacter aceti TK $0720^{\mathrm{T}}$ & 13 & 100 & 8 & 3 \\
\hline Acetobacter pasteurianus $\mathrm{TK} 0722^{\mathrm{T}}$ & 7 & 11 & 13 & 5 \\
\hline Acetobacter pasteurianus TK 0724 & 21 & 18 & 15 & 10 \\
\hline Acetobacter pasteurianus TK 0729 & 10 & 12 & 10 & 16 \\
\hline Acetobacter xylinum TK $0731^{\mathrm{T}}$ & 18 & 18 & 13 & 10 \\
\hline Acetobacter hansenii $\mathrm{TK} 0735^{\mathrm{T}}$ & 19 & 14 & 14 & 16 \\
\hline Acetobacter liquefaciens TK $0736^{\mathbf{T}}$ & 24 & 12 & 14 & 22 \\
\hline Gluconobacter oxydans TK $0740^{\mathrm{T}}$ & 15 & 15 & 100 & 8 \\
\hline Acidiphilium cryptum TK $0711^{\mathrm{T}}$ & 11 & 2 & 2 & 100 \\
\hline Acidiphilium sp. strain TK 0718 & 12 & 2 & 3 & 58 \\
\hline Acidiphilium angustum TK $0714^{\mathrm{T}}$ & 14 & 6 & 5 & 27 \\
\hline Acidiphilium facilis TK $0715^{\mathrm{T}}$ & 11 & 3 & 4 & 15 \\
\hline T. novellus TK $0901^{\mathrm{T}}$ & 14 & 4 & 4 & 25 \\
\hline T. versutus TK $3101^{\mathrm{T}}$ & 16 & 3 & 6 & 19 \\
\hline
\end{tabular}


TABLE 6. Characteristics which differentiate the genus Acidomonas from related genera

\begin{tabular}{|c|c|c|c|c|c|c|c|c|}
\hline \multirow[b]{2}{*}{ Genus } & \multirow[b]{2}{*}{ Type species } & \multirow[b]{2}{*}{ Flagellation } & \multicolumn{3}{|c|}{ Utilization of: } & \multirow[b]{2}{*}{$\begin{array}{l}\mathrm{G}+\mathrm{C} \\
\text { content } \\
(\mathrm{mol} \%)\end{array}$} & \multirow[b]{2}{*}{ Major hydroxy acid(s) } & \multirow[b]{2}{*}{$\begin{array}{l}\text { Quinone } \\
\text { system }\end{array}$} \\
\hline & & & 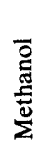 & 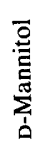 & 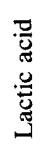 & & & \\
\hline Acidomonas & Acidomonas methanolica & - & + & - & - & $63-66$ & $3-\mathrm{OH} \mathrm{C} \mathrm{C}_{16: 0}, 2-\mathrm{OH} \mathrm{C} \mathrm{C}_{16: 0}$ & Q-10 \\
\hline Acetobacter & Acetobacter aceti & + (Peritrichous) & - & + & + & $56.5^{a}$ & $3-\mathrm{OH} \mathrm{C} \mathrm{C}_{16: 0}, 2-\mathrm{OH} \mathrm{C} \mathrm{C}_{16: 0}$ & Q-9 \\
\hline Gluconobacter & Gluconobacter oxydans & + (Polar) & - & + & - & $60.1^{a}$ & $3-\mathrm{OH} \mathrm{C} \mathrm{C}_{16: 0}, 2-\mathrm{OH} \mathrm{C}_{16: 0}$ & $\mathrm{Q}-10$ \\
\hline Acidiphilium & Acidiphilium cryptum & + (Polar) & - & + & - & $66.2^{a}$ & $3-\mathrm{OH} \mathrm{C} 14: 0$ & Q-10 \\
\hline
\end{tabular}

${ }^{a}$ Data for the type strain in this study.

DNA-DNA hybridization tests with the type strain of Acetobacter methanolicus and "Acetobacter sadu" and a clear separation from the reference strains. Therefore, these bacteria fall into a single taxon and can be identified phenotypically and genotypically as Acetobacter methanolicus.

The group 7 bacteria are distinguished from Acidiphilium strains, Thiobacillus acidophilus, $T$. novellus, $T$. versutus, and Gluconobacter and Acetobacter strains by phenotypic and chemotaxonomic characteristics (Tables 2, 4, and 5) (1, $7,28,30,32)$. Gossele et al. (5) reported that some strains of Acetobacter pasteurianus utilize methanol, but the three strains which these authors reported to utilize methanol did not utilize methanol in this study.

After considering the phenotypic and chemotaxonomic characteristics of these acidophilic, facultatively methylotrophic, nonmotile, gram-negative, rod-shaped organisms, we believe that it is appropriate to separate Acetobacter methanolicus from Acetobacter and establish a new genus, Acidomonas, for this group of bacteria. We designate Acidomonas methanolica comb. nov. as the type species of this genus. The type strain is Acidomonas methanolica TK 0705 . The minimal characteristics for differentiating the genus Acidomonas from related genera are shown in Table 6.

Description of Acidomonas gen. nov. Acidomonas (A. ci. do. mo'nas. Gr. adj. acid, acid; Gr. n. monas, unit, monad; M. L. fem. n. Acidomonas, acidophilic monad). The type species is Acidomonas methanolica (Uhlig et al. 1986) Urakami, Tamaoka, Suzuki, and Komagata comb. nov. The essential characteristics of the genus are given in Table 6 and in the description of the single species, Acidomonas methanolica.

Description of Acidomonas methanolica (Uhlig, Karbaum, and Steudel 1986) Urakami, Tamaoka, Suzuki, and Komagata comb. nov. Acidomonas methanolica (Synonym, Acetobacter methanolicus Uhlig, Karbaum, and Steudel 1986). The characteristics of the species are those reported by Uhlig et al. (21) and those determined in this study.

The cells are nonsporeforming, gram-negative rods with rounded ends that are 0.8 to 1.0 by 1.5 to $3.0 \mu \mathrm{m}$. The cells occur singly, rarely in pairs, and are nonmotile.

Colonies on PYM medium ( $\mathrm{pH} \mathrm{4.5)} \mathrm{are} \mathrm{shiny,} \mathrm{smooth,}$ raised, entire, white to light yellow, and 2 to $3 \mathrm{~mm}$ in diameter after 3 days at $30^{\circ} \mathrm{C}$. A water-soluble fluorescent pigment is not produced. Nitrate is not reduced to nitrite. The Voges-Proskauer test is negative. Indole and hydrogen sulfide are not produced. Hydrolysis of gelatin and starch is not observed. Ammonia is produced. Litmus milk is not changed. Dihydroxyacetone is not produced from glycerol. Acetic acid is produced from ethanol. Acid is produced from D-glucose oxidatively, but not from L-arabinose, D-xylose, D-mannose, D-fructose, D-galactose, maltose, sucrose, lac- tose, trehalose, D-sorbitol, D-mannitol, inositol, glycerol, or soluble starch. Acid is not produced fermentatively. Utilizes methanol, ethanol, acetic acid, D-glucose, glycerol, and pectin as sole carbon sources for energy and growth, but does not utilize L-arabinose, D-xylose, D-fructose, D-galactose, maltose, sucrose, lactose, trehalose, D-sorbitol, Dmannitol, inositol, soluble starch, citric acid, lactic acid, methylamine, methane, or hydrogen. Some strains utilize D-mannose weakly (Table 2). Calcium panthothenate is required. Ammonia, nitrate, and urea are utilized as nitrogen sources. Urease, oxidase, and catalase are produced. Aerobic. Metabolism is strictly respiratory and not fermentative.

Growth occurs between $\mathrm{pH} 2.0$ and 5.5. Good growth occurs between $\mathrm{pH} 3.0$ and 5.0. Growth does not occur above $\mathrm{pH} 6.0$ and below $\mathrm{pH} 1.5$. Good growth occurs at $30^{\circ} \mathrm{C}$ and $37^{\circ} \mathrm{C}$, but does not occur at $42^{\circ} \mathrm{C}$. Growth does not occur in the presence of $3 \%$ sodium chloride.

The DNA base composition is $64.4 \mathrm{~mol} \% \mathrm{G}+\mathrm{C}$ (type strain) (variable from 63 to $65 \mathrm{~mol} \% \mathrm{G}+\mathrm{C}$ [Table 4]). The cellular fatty acids are composed of a large amount of straight-chain unsaturated $C_{18: 1}$ acid and small amounts of straight-chain saturated $\mathrm{C}_{15: 0}$ acid, $\mathrm{C}_{16: 0}$ acid, $\mathrm{C}_{17: 0}$ acid, $\mathrm{C}_{18 \text { : }}$ 0 acid, and $C_{19: 0}$ acid, straight-chain unsaturated $C_{16: 1}$ acid, and $\mathrm{C}_{19.0}$ cyclopropane acid. The hydroxy acids are composed of large amounts of 3-OH $\mathrm{C}_{14: 0}$ acid, 3-OH $\mathrm{C}_{16: 0}$ acid, 2-OH $\mathrm{C}_{14: 0}$ acid, and 2-OH $\mathrm{C}_{16: 0}$ acid. The ubiquinone system is Q-10, along with ubiquinone Q-9 and minor ubiquinone Q-11 components.

The type strain is strain TK 0705 (= IMET 10945), which was isolated by Steudel et al. in $\mathbf{1 9 8 0}$. This strain has been deposited in the Zentralinstitut für Mikrobiologie und Experimentell Therapie as strain IMET 10945.

\section{ACKNOWLEDGMENTS}

We thank J. De Ley (Rijksuniversiteit, Ghent, Belgium) for supplying cultures.

\section{LITERATURE CITED}

1. Asai, T., H. lizuka, and K. Komagata. 1964. The flagellation and taxonomy of genera Gluconobacter and Acetobacter with reference to the existence of intermediate strains. J. Gen. Appl. Microbiol. 10:95-126.

2. Christensen, W. B. 1946. Urea decomposition as means of differentiating Proteus and Paracolon cultures from each other. J. Bacteriol. 52:461-466.

3. De Ley, J., M. Gillis, and J. Swings. 1984. Family VI. Acetobacteraceae Gillis and De Ley $1980,23^{\mathrm{VP}}$, p. 267-278. In N. R. Krieg and J. G. Holt (ed.), Bergey's manual of systematic bacteriology, vol. 1. The Williams \& Wilkins Co., Baltimore.

4. Gillis, M., and J. De Ley. 1980. Intra- and intergeneric similarities of the ribosomal ribonucleic acid cistrons of Acetobacter and Gluconobacter. Int. J. Syst. Bacteriol. 30:7-27. 
5. Gossele, F., J. Swings, K. Kersters, P. Pauwel, and J. De Ley. 1983. Numerical analysis of phenotypic features and protein gel electropherograms of a wide variety of Acetobacter strains. Proposal for the improvement of the taxonomy of the genus Acetobacter Beijerinck 1898, 215. Syst. Appl. Microbiol. 4:338368.

6. Guay, R., and M. Silver. 1975. Thiobacillus acidophilus sp. nov.; isolation and some physiological characteristics. Can. J. Microbiol. 21:281-288.

7. Harrison, A. P., Jr. 1981. Acidiphilium cryptum gen. nov., sp. nov., heterotrophic bacterium from acidic mineral environments. Int. J. Syst. Bacteriol. 31:327-332.

8. Harrison, A. P., Jr. 1983. Genomic and physiological comparisons between heterotrophic thiobacilli and Acidiphilium cryptum, Thiobacillus versutus sp. nov., and Thiobacillus acidophilus nom. rev. Int. J. Syst. Bacteriol. 33:211-217.

9. Harrison, A. P., Jr., B. W. Jarvis, and J. J. Johnson. 1980. Heterotrophic bacteria from cultures of autotrophic Thiobacillus ferrooxidans: relationships determined by means of deoxyribonucleic acid homology. J. Bacteriol. 143:448-454.

10. International Journal of Systematic Bacteriology. 1983. Validation of the publication of new names and new combinations previously effectively published outside the IJSB. List no. 12 . Int. J. Syst. Bacteriol. 33:896-897.

11. International Journal of Systematic Bacteriology. 1984. Validation of the publication of new names and new combinations previously effectively published outside the IJSB. List no. 14. Int. J. Syst. Bacteriol. 34:270-271.

12. International Journal of Systematic Bacteriology. 1984. Validation of the publication of new names and new combinations previously effectively published outside the IJSB. List no. 16. Int. J. Syst. Bacteriol. 34:503-504.

13. Kaneko, T., R. Nozaki, and K. Aizawa. 1978. Deoxyribonucleic acid relatedness between Bacillus anthracis, Bacillus cereus, and Bacillus thuringiensis. Microbiol. Immunol. 22:639-641.

14. Katayama-Fujimura, Y., N. Tsuzaki, and H. Kuraishi. 1982. Ubiquinone, fatty acid and DNA base composition determination as a guide to the taxonomy of the genus Thiobacillus. J. Gen. Microbiol. 128:1599-1611.

15. Rigby, P. W. J., M. Dieckmann, C. Rhodes, and P. Berg. 1977. Labeling deoxyribonucleic acid to high specific activity in vitro by nick translation with DNA polymerase I. J. Mol. Biol. 113: 237-251.

16. Saito, J., and K. Miura. 1963. Preparation of transforming deoxyribonucleic acid by phenol treatment. Biochim. Biophys. Acta 72:619-629.

17. Skerman, V. B. D., V. McGowan, and P. H. A. Sneath (ed.). 1980. Approved lists of bacterial names. Int. J. Syst. Bacteriol. 30:225-420.

18. Steudel, A., D. Miethe, and W. Babel. 1980. Bakterium M58, ein methylotrophs "Essigusäurebakterium." Z. Allg. Mikrobiol. 20:663-672.

19. Tamaoka, J., and K. Komagata. 1984. Determination of DNA base composition by reversed-phase high-performance liquid chromatography. FEMS Microbiol. Lett. 25:125-128.

20. Taylor, B. F., and D. S. Hoare. 1969. New facultative Thiobacillus and a reevaluation of the heterotrophic potential of
Thiobacillus novellus. J. Bacteriol. 100:487-497.

21. Uhlig, H., K. Karbaum, and A. Steudel. 1986. Acetobacter methanolicus sp. nov., an acidophilic facultatively methylotrophic bacterium. Int. J. Syst. Bacteriol. 36:317-322.

22. Urakami, T., and K. Komagata. 1984. Protomonas, a new genus of facultatively methylotrophic bacteria. Int. J. Syst. Bacteriol. 34:188-201.

23. Urakami, T., and K. Komagata. 1986. Methanol-utilizing Ancylobacter strains and comparison of their cellular fatty acid composition and quinone systems with those of Spirosoma, Flectobacillus, and Runella species. Int. J. Syst. Bacteriol. 36: 415-421.

24. Urakami, T., and K. Komagata. 1986. Occurrence of isoprenoid compounds in gram-negative methanol-, methane-, and methylamine-utilizing bacteria. J. Gen. Appl. Microbiol. 32:317-341.

25. Urakami, T., and K. Komagata. 1987. Cellular fatty acid composition with special reference to the existence of hydroxy fatty acids in gram-negative methanol-, methane-, and methylamineutilizing bacteria. J. Gen. Appl. Microbiol. 33:135-165.

26. Urakami, T., J. Tamaoka, and K. Komagata. 1985. DNA base composition and DNA-DNA homologies of methanol-utilizing bacteria. J. Gen. Appl. Microbiol. 31:243-253.

27. Urakami, T., I. Terao, and I. Nagai. 1981. Process for producing bacterial single cell protein from methanol, p. 349-359. In Proceddings of the Third International Symposium on Microbial Growth on $\mathrm{C}_{1}$ Compounds. Heyden \& Son Ltd., Spectrum House, London.

28. Wichlacz, P. L., R. F. Unz, and T. A. Langworthy. 1986. Acidiphilium angustum sp. nov., Acidiphilium facilis sp. nov., and Acidiphilium rubrum sp. nov.: acidophilic heterotrophic bacteria isolated from acidic coal mine drainage. Int. J. Syst. Bacteriol. 36:197-201.

29. Yamada, Y. 1983. Acetobacter xylinus sp. nov., nom. rev., for the cellulose-forming and cellulose-less, acetate-oxidizing acetic acid bacteria with the Q-10 system. J. Gen. Appl. Microbiol. 29: 417-420.

30. Yamada, Y., K. Aida, and T. Uemura. 1969. Enzymatic studies on the oxidation of sugar and sugar alcohol. V. Ubiquinone of acetic acid bacteria and its relation to classification of genera Gluconobacter and Acetobacter, especially of the so-called intermediate strains. J. Gen. Appl. Microbiol. 15:181-196.

31. Yamada, Y., and M. Akita. 1984. An electrophoretic comparison of enzymes in strains of Gluconobacter species. J. Gen. Appl. Microbiol. 30:115-126.

32. Yamada, Y., M. Akita, T. Koda, Y. Tahara, and H. Yoshioka. 1983. Elevation of Acetobacter aceti subsp. liquefaciens to Acetobacter liquefaciens sp. nov. comprising the peritrichously flagellated intermediate in acetic acid bacteria. J. Gen. Appl. Microbiol. 29:327-333.

33. Yamada, T., T. Ishikawa, M. Yamashita, Y. Tahara, K. Yamasato, and T. Kaneko. 1981. Deoxyribonucleic acid base composition and deoxyribonucleic acid homology in acetic acid bacteria, especially in the polarly flagellated intermediate strains. J. Gen. Appl. Microbiol. 27:465-475.

34. Yamada, Y., M. Nunoda, T. Ishikawa, and Y. Tahara. 1981. The cellular fatty acid composition in acetic acid bacteria. J. Gen. Appl. Microbiol. 27:405-417. 